\author{
Ilhama SULTANOVA, \\ orcid.org/0000-0002-2003-9899 \\ Doctoral Student at the Department of Azerbaijan-Turkmenistan-Uzbekistan Literary Relations \\ Institute of Literature named after Nizami Ganjavi of National Academy of Sciences of Azerbaijan \\ (Baku,Azerbaijan) silhame@books.ru
}

\title{
“MOLLA NASRADDIN" AND THEMATIC-PROBLEMATIC PARALLELS IN UZBEK SATIRICAL POETRY
}

The article emphasizes the need for a more comprehensive and systematic study of the influence of the founders of "Molla Nasraddin" in the formation of Uzbek satirical poetry. The reasons for the great popularity and love of the journal "Molla Nasraddin" in general among Turkestan, as well as Uzbek readers, poets and writers, scientists are clarified. Among the main reasons are that the stylistic of "Molla Nasraddin" is an original aesthetic event, the journal regularly and consistently covers the life of the Turkestan people in its pages, pays attention to news, events and innovations from different cities and regions, and sympathizes with the intolerable lives of its Muslim and Turkish brothers. The role of the founders of "Molla Nasraddin" in the formation of Uzbek satirical poetry is studied in the context of the Turkestan areal. Works written by founders of "Molla Nasraddin" on the life of the fraternal country, one of the bright pages of Azerbaijan-Turkestan literary and cultural relations in 1905-1920 - topical satires of J.Mammadguluzadeh, the satires of M. A. Sabir, A. Gamkusar, A. Nazmi and other founders of "Molla Nasraddin" are involved into the analysis, the main focus is on the criticism of the Bukhara Khanate, which became almost a symbol of medieval feudal backwardness, religious superstition and ignorance, not only in Turkestan, but in the Middle East as a whole. The analysis is carried out in comparison with the works of well-known Uzbek enlightenment writers and poets - Abdulla Avlani, Makhmudhoja Behbudi, Siddiqi Ajzi, Mirmohsun Shirmahammadov, Abdurauf Fitrat, Abdulla Gadiri, Ali Fitrat and others. The influence of the founders of "Molla Nasraddin" is confirmed by literary materials. The article concludes that the study of the problem of "Molla Nasraddin" literary school and Uzbek satirical literature" on a scientific-theoretical level and literary-historical sequence creates unique opportunities to clarify the main tendencies and foundations of literary and cultural relations of Azerbaijan and Uzbekistan in the twentieth century. The second half of the 19th century and the beginning of the 20th century are considered to be a special period as well as a transitional period in the centuries-old history of Turkestan-Azerbaijani literary relations. It is a literary-historical fact that the idea-aesthetic and socio-political content of this special stage is determined by the creative activity of the journal "Molla Nasraddin" and its founders, as well as cooperation with Uzbek intellectuals, poets and writers. The opinions and judgments put forward in the article are based on the scientific conclusions of well-known Azerbaijani and Uzbek literary critics.

Key words: journal "Molla Nasraddin", founders of "Molla Nasraddin", J. Mammadguluzadeh, M. A. Sabir, Uzbek satirical literature, jadids, A. Avlani, S. Ajzi, A. Gadiri, A. Fitrat.

Ілхама СУЛТАНОВА,

orcid.org/0000-0002-2003-9899

докторант кафедри азербайджансько-туркменсько-узбекистанських літературних відносин Інституту літератури імені Нізамі Ганджеві Національної академії наук Азербайджану

(Баку, Азербайджан) silhame@books.ru

\section{«MOLLA NASRADDIN» I ТЕМАТИЧНО-ПРОБЛЕМАТИЧНІ ПАРАЛЕЛІ У САТИРИЧНІЙ ПОЕЗІЇ УЗБЕКИСТАНУ}

У статті наголошується на необхідності всебічного та систематичного вивчення впливу засновників «Молли Насраддіна» на формування узбецької сатиричної поезї. 3'ясовано причини великої популярності та любові журналу «Molla Nasraddin» загалом серед Туркестану, а також узбецьких читачів, поетів $і$ письменників, науковців. Основними причинами є те, щчо стилістика «Molla Nasraddin»- оригінальна естетична подія, журнал висвітлює життя туркестаниів на своїх сторінках, звертає увагу на новини, події та інновації з різних міст і регіонів, а також співчуває нестерпному життю турецьких братів-мусульман. Роль засновників «Молли Насраддіна» у формуванні узбецької сатиричної поезї вивчається в контексті Туркестанського ареалу. Твори, написані засновниками «Молла Насраддін» про життя братньої крайни, одні з яскравих сторінок азербайджано-туркестанських літературних і культурних відносин у 1905-1920 рр. - актуальні сатири Дж. Мамедгулузаде, сатири М. А. Сабіра. До аналізу залучені Гамкусар, А. Назмі та інші засновники «Молла Насраддін», основна увага приділяється критииі Бухарського ханства, яке стало чи не символом середньовічної феодальної відсталості, релігійних забобонів і невігластва не тільки в Туркестані, але і на Близькому Сході загалом. Аналіз проводиться у порівнянні із творами відомих узбецьких письменників-просвітителів - Абдулли Авлані, Махмудходжа 
Бехбуді, Сіддікі Айзі, Мірмохсуна Ширмахаммадова, Абдурауфа Фітрата, Абдулли Гадірі, Алі Фітрата та ін. Вплив засновників «Молли Насраддіна» підтверджується літературними матеріалами. У статті робиться висновок, шзо вивчення проблеми літературної иколи «Молла Насраддін» та узбецької сатиричної літератури на науково-теоретичному рівні та літературно-історичній послідовності створює унікальні можливості для з'ясування основних тенденцій літературних і культурних відносин Азербайджану й Узбекистану у ХХ ст. Друга половина XIX і початок XX cm. вважаються особливим періодом, а також перехідним періодом у багатовіковій історї туркестано-азербайджанських літературних відносин. Літературно-історичним фактом є те, щзо ідейно-естетичний $і$ сочіально-політичний зміст ичього етапу визначається творчою діяльністю журналу «Молла Насраддін» і його засновників, а також співпрацею з узбеиькими інтелектуалами, поетами та письменниками. Викладені у статті думки та судження трунтуються на наукових висновках відомих азербайджанських та узбецьких літературознавців.

Ключові слова: журнал «Molla Nasraddin», засновники «Molla Nasraddin», Й. Мамедгулузаде, М. А. Сабір, узбецька сатирична література, джадіди, А. Авлані, С. Аджзі, А. Гадірі, А. Фітрат.

Introduction. There were many reasons why the journal "Molla Nasraddin" was met with interest by readers in Turkestan, as well as literary figures, writers and poets. One of them, and the first, was the bold and unique writing style of the journal's authors. The founders of "Molla Nasraddin" brought an unprecedented and unused style of expression to the Middle Eastern literature with their writing and idiom styles, inikas and stylistic manners. This new manner and style of communication with readers was of great interest to everyone, especially the writers. Of course, satires were written in Eastern literature even before "Molla Nasraddin". Even in the works of Navai and Fuzuli, we observe signs of satire and satirical style. But the style of "Molla Nasraddin" was a completely new, unprecedented aesthetic phenomenon due to its scale and revealing quality. Another important reason for "Molla Nasraddin"s unparalleled popularity and resonance in Turkestan was the journal's regular and consistent coverage of the life of the Turkestan people in its pages. As the founders of "Molla Nasraddin" described the deformities, injustices and tragedies in Iran, South Azerbaijan, Turkey, Arabia and other Muslim countries with heart and a great fire of bigotry, they also wrote about the terrible scenes of Turkestan's life with the same and deep care and brotherly love, and felt sorry for the plight of their Muslim and Turkish brothers. From this point of view, bringing the problem of Turkestan life to the center of analysis in the journal "Molla Nasraddin" is of special importance from the point of view of studying the international interests and scope of the journal, as well as the next stage of Azerbaijani-Turkestan spiritual and cultural relations.

Discussion. As we have noted, one of the bright pages of the Azerbaijani-Turkestan literary and cultural relations in 1905-1920 is the works of the founders of "Molla Nasraddin" about the life of the fraternal country. In J. Mammadguluzadeh's feuilletons on this subject, in the angry and belligerent satires of M. A. Sabir, A. Gamkusar, A.Nazmi and other "Molla Nasraddin" satirists, we see that Turkestan society exposed to various problems and deformities. It should also be noted that the pages of the journal reflected the news from different cities and regions of Turkestan, events and innovations that took place in different parts of the country. However, the most satirical image in "Molla Nasraddin" was the Bukhara khanate, the city of Bukhara, which is already known and popular with a wide readership. The main reason for such a strong interest in Bukhara in the works of Azerbaijani enlightener writers and satirists was the fact that the city almost became a symbol of medieval feudal backwardness, religious superstition and ignorance, not only in Turkestan but in the Near East as a whole. The point is that the socio-political system and economic and cultural backwardness of the Bukhara Khanate were sharply criticized not only in the works of the founders of "Molla Nasraddin", but also in the works of Uzbek enlightener writers and satirists. For instance, well-known Uzbek enlightener writers and poets Abdulla Avlani, Makhmudhoja Behbudi, Siddiqi Ajzi, Mirmohsun Shirmahammadov, Abdurauf Fitrat, Abdulla Gadiri and others wrote in their articles and feuilletons about the city that Bukhara was far behind the innovations of the modern world wrote that people lived under oppression, in a state of lawlessness as slaves and they disgraced the government of this country all over the world. Prominent enlightener-poet, writer and playwright A.Fitrat wrote in his "Munozara" (1911), "Bayonoti sayyohi hindi" (1912), "Qiyomat" (1913), "Nara" (1914), "Oila" (1915) and many other literary and philosophical works, against the background of comparisons with the lives of the peoples of Europe, he summarized the horrible human landscapes of Bukhara and called on his Muslim brothers to get tired of such a life and to radically change their way of life and thinking.

It was not accidental that in the pages of "Molla Nasraddin" and in the works of Uzbek Jadids, the methods of governing the Bukhara Emirate and the feudal-patriarchal way of life in this region were consistently exposed, both in sharp literary and satirical styles. Indeed, in the early twentieth century, the situ- 
ation in Bukhara was extremely difficult and deplorable. Despite the occupation of the Bukhara Khanate by the Russian Empire and maintaining its formal political independence over other regions and provinces of Turkestan, the level of socio-economic development and the dominance of feudal relations were extremely intolerable and desperate. Compared to other provinces of Turkestan, economic and cultural backwardness, medieval feudal traditions, religious fanaticism and superstition covered all spheres of life and activity of the Bukhara khanate like a spider's web. The emirs of Bukhara still preferred to use typical and primitive medieval feudal rules, traditional methods of violence and torture. The formal independence of the Bukhara Khanate in comparison Tsarist Russia did not have any socio-political significance, because in fact this region was one of the dozens of colonies of the Russian Empire that had no rights with them.

Thus, the widely spread of the spiritual and moral crisis, the collapse of economic life and the country's economy, the outbreak of superstition and ignorance among the masses, the almost collapse of science and education, enlightenment and culture were the leading features that characterized the social and spiritual life of the Bukhara Khanate in the early twentieth century. J.Mammadguluzadeh, who knew the life of the peoples of the East deeply and perfectly, worked with all his might to get rid of their feudal inertia and slavery, was considered one of the bravest and most powerful artists of his time, in his feuilleton "Jackal" (1909) he criticized the rotten morality of the Bukhara emirs, who forgot their homeland and nation, the representatives of the reactionary religious-feudal government hegemony in the country, the poor and pious Muslims who did not even think of waking up from the "ignorance" of Bukhara. The tragedies of Bukhara, along with Mirza Jalil, were in the spotlight of other founders of "Molla Nasraddin" and often became the target of satire and criticism. In this regard, the work of the most prominent representative of satirical poetry in "Molla Nasraddin" M. A. Sabir is also important. In general, it should be noted that Sabir's satires have a special role in the satirical poetry of XX century Azerbaijan in the reflection of Bukhara themes and problems. In the satire that begin with the beyt "Zahid wants to reach his goal before he dies, he wants to throw a a sleep noose around Paradise" of the great poet, he exposed the moral depravity of the believers in Bukhara and their suffering in the bondage of ignorance (Sabir, 2004a: 243).

Exposing the despotic rulers of the Old East of the twentieth century with terrible and ironic qualities - Sultan Abdulhamid, Mahammadali Shah, Zilli Sultan, Rahim khan and other ruthless rulers, the poet does not forget the emirs of Bukhara, Ahad khan and Amir Alimkhan, engraved them along with dozens of others on the board of shame and condemnation (Sabir, 2004b: 275).

The international content and significance of M.A.Sabir's poetry was that among the objects of criticism of his sharp satirical pen could be seen the Tsarist government, British imperialism, Iranian shahs and Arab emirs, Turkish sultans, Turkestan authorities, including the emirs of Bukhara. In the pages of "Molla Nasraddin" and Sabir's satires, along with the revolutionary events in Moscow and St.Petersburg, Kazan and Ufa, Baku and Tabriz, important political events in many cities and regions of Turkey, Iran and Turkestan were reflected. The most important thing here is that the genius Sabir describes the socio-political events and processes that took place in the above-mentioned places in his work in connection with the most advanced worldview and democratic ideals of his time, he praised the democratic changes taking place in the socio-cultural life of the oppressed peoples of the East. Prominent Uzbek literary critic T.Jalalov, speaking about these important and characteristic features of Sabir's work, emphasizes the following: "M. A. Sabir's satire on fire reflects not only the fate of the Azerbaijani people, but also the difficult and tragic past of the Turkestan nations. This was one of the features that brought Sabir to the attention of Uzbek readers and people" (Calalov, 1964).

In M. A. Sabir's condolences, which began with the hemistiches "Report ehyayi-Samarkand made an Iranian merchant" and "Some holy ulema who are enemies of the school" the extreme backwardness of the Turkestan environment, the "saints" of this ignorance and feudal inertia, the enemies of science and enlightenment, the reactionary forces resisting innovation and development with all their being, and the old-fashioned people were angrily exposed (Sabir, 2004c: 319).

The great satirist did not see any serious difference between the religious fanatics in the Caucasus, the hard believers in Shamakhi and their allies in Kokand, and the ignorant in Bukhara on the contrary, he fired all the forces of superstition and fanaticism with the same rage and passion, with sharp satire (Sabir, 2004d: 19).

A.Gamkusar's satire with radif "Bukhara" is one of the unique examples of sharp public criticism in the democratic poetry of Azerbaijan in 1905-1920, but also can be considered as a bright example in terms of the reflection of the Turkestan theme in the brotherly Azerbaijani literature. Letters and news sent from different cities of Turkestan to the editorial office of "Molla Nasraddin" journal played an important role 
in the creation of this poem, rather than the author's direct travel impressions. Written in the style of bitter irony and with the power of deep revelation, this poem draws attention to the social pathos and drama born of the combination of sharp satirical harmony and mercy-compassion. In general, it is important to note that the organic unity of public concern with bitter and poisonous laughter in poetry and the pathos of national tragedy resulting from this unity are realized as one of the aesthetic qualities inherent in the style of expression of "Molla Nasraddin" school representatives. The poet is so moved by the horrors of Bukhara that he compares this tragedy to the plight of Muslims in Iran, Egypt, Tunisia and Sudan, but finds no consolation (Qamkusar, 2006a: 39).

In 1916, A.Gamkusar traveled to Turkestan together with the author and close friend J.Mammadguluzadeh to organize performances of the comedy "Deads" (1909) in Central Asian cities. Both founders of "Molla Nasraddin" see the socio-cultural life of Ashgabat, Merv, Bukhara, Samarkand, Tashkent and the life of local people, with whom they have repeatedly published news and feuilletons. This journey, of course, deepens and enriches the thoughts and ideas of both artists about Turkestan. It is interesting that A.Gamkusar wrote about his travel impressions while he was still in Tashkent, sent by letter to the "Achiq Soz" newspaper, and in that article he talks about the life of the people of Turkestan, the state of socio-cultural relations there. Prominent literary scholar, prof. Islam Agayev speaking about this letter in his monograph, states the following: "In a letter to the "Achiq Soz" newspaper, Aligulu Gamkusar spoke with deep sorrow about the lifestyle of the Uzbek people and the gravity of the cultural and economic situation in the country" (Agayev, 1976: 65).

A.Gamkusar's satire with radif "Başa Gəlməz" written in 1917 on the basis of impressions of the trip gives the impression of a poetic continuation of the publicist's article published in "Achiq soz" newspaper. In this satire, the poet described what he saw with his own eyes in Turkestan (Qamkusar, 2006b: 81). In addition to these satires, A.Gamkusar's feuilletons "Year of the Tiger" (1914), "Not of the Runner, but of the Commander" (1917) and other works spoke in detail about the problems of Turkestan, the difficult socio-economic environment and intolerable situation of the Turkic people living here were discussed, and the dominance of medieval rules and feudal traditions in the cities of Central Asia was sharply criticized.

It is important to consider a number of fundamental works by Uzbek enlightener writers in order to compare the similarities between the founders of
"Molla Nasraddin" and the socio-political platform and enlightenment programs of the Jadids. From this point of view, it is necessary to emphasize Abdurauf Fitrat's "Munozara", "Oila", Makhmudhoja Behbudi's "Padarkush", articles and letters of many Uzbek Jadids directly related to this topic. Uzbek literary critics emphasize the great importance of A. Fitrat's work "Munozara" ("Dispute") in the expansion of the enlightenment movement and struggle in Turkestan. This work has an incomparable value in terms of expressing the socio-aesthetic and enlightional-cultural content of the Uzbek Jadid movement. Written in the style of conversation-dialogue, "Munozara" was written by A.Fitrat in Persian during his stay in Istanbul. The story was first translated into Turkish (i.e. Uzbek - I. S) in 1911 on the recommendation of Makhmudhoja Behbudi, a well-known enlightener writer Haji Muin Shukrulla. The work was published in the same year in the "Turkistan Province Newspaper" and then in a separate booklet. This translation of "Munozara" was carried out with certain interventions and edits, as the work was intended to be staged. In the process of translation, taking into account the interest and level of the audience at that time, certain parts of the work were shortened, and the language and style were adapted to the stage. Despite all these interventions and forced distortions, the work "Munozara" spread like lightning speed in Turkestan and became popular. This work brought world fame to A. Fitrat, his most famous contemporaries, new friends and comrades-in-arms M. Behbudi, S. Aini, F. Khojayev, H. Shukrulla and others emphasized the high ideological and aesthetic features of the work and its great resonance in the cultural environment of Turkestan. The text of the "Munozara" has been published several times in Bombay (1929), Karachi (1942), Dushanbe (1996), Japan, the United States and a number of European countries.

The following remarks of Makhmudhoja Behbudi, one of the leaders and founders of the Turkestan Jadid movement, the first critic of the "Munozara", are still relevant today, despite the fact that they were expressed 110 years ago: "The conversation between a French gentleman and a mudarris from Bukhara about the benefits of usul-i Jadid schools and the need for education for the people of Bukhara during the development of science was published in Persian in the form of a treatise entitled "Munozara". We also reviewed and made sure that this story is really beneficial for the people of Bukhara. We express our deep gratitude to those who edited and published this important treatise given by French man and mudarris. Inshallah, this treatise will awaken the people of Bukhara, and the author and editor of the "Muno- 
zara" will always be remembered with gratitude" (Behbudiy, 1911).

The work discusses the state of science and education in all Turkestan and Eastern countries on the basis of a dialogue between a mudarris from Bukhara and a Frenchman. The author's purpose was not only to deny education system that outdated and does not meet the requirements of the time. During the dialogue between Firangi and Mudarris, important thoughts are put forward about the reasons why Bukhara scholars and intellectuals drowned in the swamp of ignorance and why the people lived in difficult and intolerable conditions. Among the main reasons behind the terrible social situation in Turkestan, especially in the Bukhara khanate, A. Fitrat points to the rule of the Emirate in Bukhara, Amir Alimkhan and his entourage, which caused this great Eastern city and province to groan under colonial oppression, as well as the real face of the occupation policy of Russian tsarism. As a result of the severity and veracity of these accusations, not only the Emir and his nobles, but also the fanatical and ignorant mullahs of Bukhara, Russian judges and officials in Turkestan did not stop the persecution of A.Fitrat and "Munozara". It is heartbreaking to note that the population of an ancient and beautiful land like Bukhara, once a population of about ten million, has shrunk to 2 million since Russia's invasion, with only 70,000 of them living in the capital, Bukhara and the idea that nine out of tenths of this 70,000-strong urban population is completely illiterate.

All the pages of the "Munozara" are full of the passion of the enlightener philosopher and writer to save, recreate and modernize the Islamic world, especially his homeland Bukhara. The enlightenment-philosophical views of the Turkestan Jadids were not so accurately and effectively reflected in any book of that period. A.Fitrat appeals to the leadership, people and every citizen of the country to save his homeland, which is far behind the pace of renewal and growth of the world and time, with a heart-wrenching and conscientious cry. In the speech of the great writer, almost all the elements and methods of appeal, which will affect a person, were skillfully used. In this sense, the "Munozara" is truly a typical and classic example of enlightening publicity and prose: "Islam is our religion, Islam is our honor, Islam is our happiness. Islam is the cause of our pride, Islam is the main reason for our peace and spiritual comfort. Bukhara is our holy Homeland. Bukhara is our affectionate mother. Bukhara is our place of divinity, Bukhara is our place of worship. Bukhara is our dear mistress. Bukhara is our beloved along with our souls. Bukhara is from us, we are from Bukhara. It is enough we have spent so much of our lives in ignorance and laziness, captured in ignorance and illiteracy. Neither our Shari'ah, nor our customs and traditions will ever forgive you for the loss of this dear religion, for the dishonorable acceptance of the share of this sacred Motherland. Perhaps today, all the sages and scientists of the world, the progressive advocates of the world community, are cursing us and consider us out of the way of humanity. Brothers! Come to your senses a little, gather your mind and consciousness. Human is the most honorable of all creatures on earth. The reason why human is different and honorable from other creatures is that human is capable of progress and decay, while other animals do not... After all, think for yourself, come to your senses, why should we face decay day by day at a time when all the disbelievers are developing in the world.?! If the disbelievers write their names as Human in the eyes of all the sages and scholars of the world, why should we be considered a "jamadat"? If the disbelievers live with perfect wealth and happiness, why should we agree to live as beggars ?!" (Fitrat, 2000a: 96-97).

A.Fitrat's angry and nervous cries, painful questions that tear a person's heartinvoluntarily reminds us the great Azerbaijani enlighteners and democrats M. F. Akhundzadeh, H. B. Zardabi, N. B. Vazirov, A. Hagverdiyev, J. Mammadguluzadeh, M. A. Sabir, M. Hadi and A. Sahhat's artistic speeches, their questions addressed to the Muslim world, mixed with cries. A. Fitrat's steadfastness in his enlightened worldview and reformer's status, the depth and scope of his thinking are astonishing in the true sense of the word: "Aren't you ashamed? Every day, Christians invent thousands of innovations, such as firecarts, fire-ships, and telegraph wires, and our industry is limited to the production of horse-drawn carriages and clay carts. Tfu, for such a dark and helpless day, we should be ashamed of the door. O readers of this booklet of mine! If our love for religion, Homeland, property, soul and children is true, if you want our religion to be saved, our law to live, our country to develop and prosper, our children to come and be safe, and to have a good name in this world, the only solution to your problems is science and education (Fitrat, 2000b: 97-98).

The resonance created at the time by A.Fitrat's "Munozara" (1911) was so magnificent and majestic that his opinion was rightly compared with the perception of "Russian Muslims" by I.Gaspirali. One of the first readers and evaluators of "Munozara", the famous contemporary of A. Fitrat, S. Aini also said on the occasion of this work: "This little story spread like wildfire and intimidated the Russian government, and the Emir and the Russian police began to per- 
secute not only the work "Munozara" but also those who read it" (Boltabayev, 1987: 10-11).

A. Fitrat's enlightening and Jadid oriented views, in general, his reformist thoughts on the changing of Bukhara and the Muslim society were not limited to the work "Munozara", but also in his successive works in various genres, including "Rohbari najot" (1913), "Mavludi Sharif" or kheyrul bashar" (1914), "Tarixi Islom" (1915), "Oila" (1916) and other works on religious and philosophical topics were expressed and substantiated. The author's first work on this subject, "Munozara", has a special unique place not only in Uzbek and Tajik, Turkestan literature, but in Muslim Eastern literature as a whole.
Conclusions. Thus, the study of "Molla Nasraddin" and thematic-problematic parallels in Uzbek satirical poetry" on a scientific-theoretical level and literary-historical sequence, in general, creates unique opportunities to clarify the main tendencies and foundations of literary and cultural relations of Azerbaijan and Uzbekistan in the twentieth century. The second half of the 19th century and the beginning of the 20th century are not only a transitional period in the history of centuries-old Turkestan-Azerbaijani literary relations, but also a special stage. The idea-aesthetic and socio-political content of this special stage is determined by the creative activity of the journal "Molla Nasraddin" and its founders, as well as cooperation with Uzbek intellectuals.

1. Ağayev İ. Đliqulu Qəmküsar. Bak1, "Elm” nəșriyyatı, 1976.

2. Behbudiy M. "Munozara" hokida. "Turkiston viloyatininq qazeti". 1911, 29 sentyabr.

3. Boltabayev Hamidulla. Fitrat və Cadidçilik. Alişir Navoi nomidaqi Özbəkiston Milli Kütibxonosi naşriyoti, Toşkent, 2007; bax : Ayni S. Tarixi inqilabi Buxara. Duşanbe, "Adib” naşriyoti, 1987.

4. Calalov T. Sobir kahkahasi. "Shark yulduzi”, 1962.

5. Qəmküsar Ә. Seçilmiş əsərlər. Bakı, "Şərq-Qərb”, 2006.

6. Fitrat Abdurauf. Tanlangan asarlar. I cild. Toshkent, "Manaviyat", 2000.

7. Sabir M.Ә. Hophopnamə. I cild. Bak1, “Şərq-Qərb”, 2004.

\section{REFERENCES}

1. Ağayev İ. Oliqulu Qəmküsar.[Aliguli Qamkusar] Baku, "Elm”, 1976. [in Azerbaijani]

2. Behbudiy M. "Munozara" hokida. [Minozara hokida]. "Newspaper of Turkestan region". September $29,1911$. [in Uzbek]

3. Boltabayev Hamidulla. Fitrat və Cadidçilik. [Fitrat and Jadidism] Alisher Navoi National Library of Uzbekistan Publishing House, Tashkent, 2007; see: Ayni S. Historical Revolution Bukhara. Dushanbe, Adib Publishing House, 1987. [in Tajik]

4. Calalov T. Sobir kahkahasi. [Patient laughter] "Star of the Shark", 1962. [in Uzbek]

5. Qəmküsar Ә. Seçilmiş əsərlər. [Selected works] Baku, "East-West", 2006. [in Azerbaijani]

6. Fitrat Abdurauf. Tanlangan asarlar.[ Selected works]. I part. Tashkent, Manaviyat, 2000. [in Uzbek]

7. Sabir M. Ә. Hophopnamə. [Hophopname] I part. Baku, "East-West”, 2004 [in Azerbaijani] 